
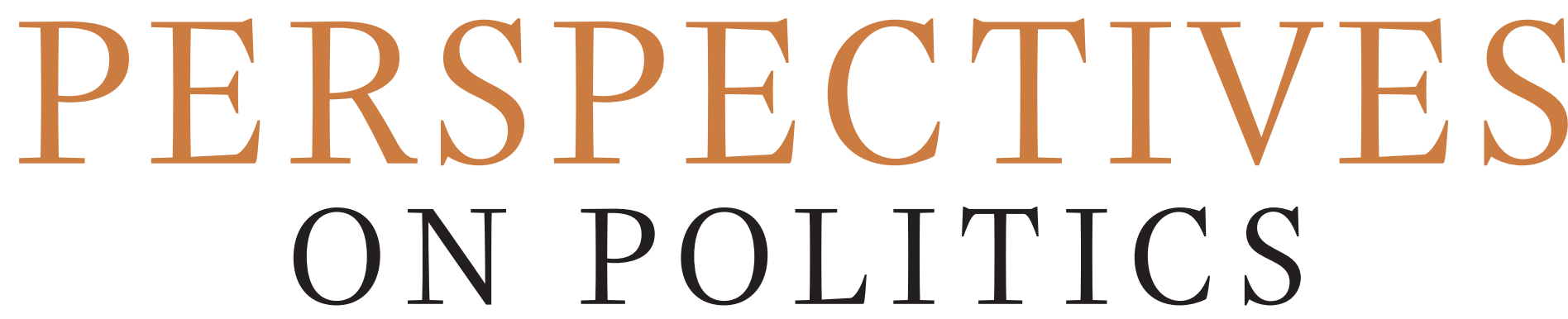

A Political Science Public Sphere | June 2010, Volume 8, Number 2

\title{
Weapon of
} the Strong? Participatory Inequality and the Internet

Kay Lehman Schlozman, Sidney Verba, and Henry E. Brady 


\section{American Political Science Association}

\section{APSA Membership Opens Doors Take Advantage of the Value of APSA Membership}

\section{As the the oldest,} largest, and most comprehensive political science society in the world, APSA

\section{supports over}

\section{4,000 members}

in 70 countries

\section{and advances}

\section{political science}

in many ways.

\section{Open the door}

to your future.

Become an APSA

member!

\section{Offering Online Scholarship}

Scholarship is central to APSA membership. Current and recent back issues of all three APSA journals are available online to members through Cambridge Journals Online. Members can also gain access to the full historical collection through JSTOR subscriptions. Political Research Online (PROL), a collaborative project led by APSA and a consortium of political science and related associations, houses 30,000 searchable conference papers.

\section{Creating Networks and Connecting Scholars}

APSA strives to provide valuable opportunities for members to network with colleagues, share ideas, and form relationships to drive their careers. Members receive discounts for APSA conferences-the Teaching and Learning Conference, Conference for Chairs, and the Annual Meeting — as well as access to the association's Organized Sections.

\section{Providing Career and Employment Resources}

APSA's eJobs is the most comprehensive online resource of political science employment opportunities and job candidates. It is fully searchable and updated daily with new job listings and candidate resumes. The eJobs placement service at the Annual Meeting brings employers and candidates together in person to greatly facilitate the hiring process.

\section{Supporting Political Science Research}

The Centennial Center for Political Science \& Public Affairs, located at APSA's headquarters building, provides office space for scholars and students conducting field work in Washington, D.C. Through the Center, APSA also offers a number of research grant opportunities for scholars working in various subfields.

\section{Membership application, rates and details: www.apsanet.org}




\section{Perspectives on Politics}

June 2010/Vol. 8, No. 2 | American Political Science Association

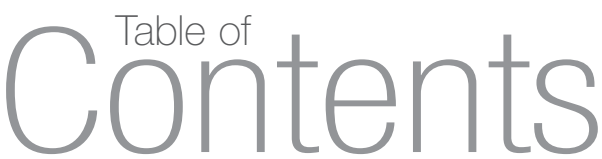

\section{Editor's Introduction}

407 Editor's Introduction

Jeffrey C. Isaac

\section{Articles}

411 Analytic Eclecticism in the Study of World Politics: Reconfiguring Problems and Mechanisms across Research Traditions

Rudra Sil and Peter J. Katzenstein

433 The Perils of Paradigm Mentalities: Revisiting Kuhn, Lakatos, and Popper

Thomas C. Walker

453 Scholasticism in Political Science

Lawrence M. Mead

465 Offensive Political Theory

Andrew Rehfeld

487 Weapon of the Strong? Participatory Inequality and the Internet

Kay Lehman Schlozman, Sidney Verba, and Henry E. Brady

511 Experimenting in Democracy Promotion: International Observers and the 2004 Presidential Elections in Indonesia

Susan D. Hyde

\section{Reflections}

529 Ballots and Barricades: On the Reciprocal Relationship between Elections and Social Movements Doug McAdam and Sidney Tarrow

543 Charles Tilly's Problem Situations: From Class and Revolution to Mechanisms and Contentious Politics

Mark Lichbach

551 Changing Mass Priorities: The Link between Modernization and Democracy Ronald Inglehart and Christian Welzel

Cover Art: What is the impact of Internet participation on long-standing patterns of participatory inequality in American politics? See inside: "The Weapon of the Strong? Participatory Inequality and the Internet" by Kay Lehman Schlozman, Sidney Verba, and Henry E. Brady. Photo provided courtesy of Alicia Hansen, founder of NYCSalt, a nonprofit photography program serving inner city teenagers in New York City (www.nycsalt.org). Website in the image: www.realclearpolitics.com. 


\section{Review Symposia}

569 Beyond the Tragedy of the Commons

A Discussion of Governing the Commons: The Evolution of Institutions for Collective Action.

By Elinor Ostrom.

Nancy Bermeo

Margaret Levi

Frank R. Baumgartner

Robert O. Keohane

Robert Axelrod

Ben Fine

Peregrine Schwartz-Shea

Jane Mansbridge

595 Collaborative Governance and Civic Empowerment

A Discussion of Investing in Democracy: Engaging Citizens in Collaborative Governance.

By Carmen Sirianni.

Margaret Weir

Leslie Lenkowsky

Romand Coles

Patrick J. Deneen

\section{Review Essay}

609 Labor and American Politics

Paul Frymer

\section{Critical Dialogue}

617 Reviews and Responses

Bruce Miroff

The Liberals' Moment: The McGovern

Thomas A. Spragens, Jr.

Insurgency and the Identity Crisis of the

Getting the Left Right: The Transformation,

Democratic Party.

Decline, and Reformation of American

Liberalism.

\section{Book Reviews}

\section{SPECIAL REVIEW SECTION: ASIA IN WORLD POLITICS}

625 Zachary Abuza, Conspiracy of Silence: The Insurgency in Southern Thailand.

Review by Robert B. Albritton

Amitav Acharya, Whose Ideas Matter? Agency and Power in Asian Regionalism.

Review by Sheldon W. Simon

Cynthia J. Buckley, Blair A. Ruble and Erin Trouth Hofmann, eds. Migration, Homeland, and Belonging in Eurasia. Review by William Fierman

Kent E. Calder and Francis Fukuyama, eds. East Asian Multilateralism: Prospects for Regional Stability.

Review by Richard Stubbs

Christian Collet and Pei-te Lien, eds. The Transnational Politics of Asian Americans. Review by Andrew L. Aoki

David B. H. Denoon, The Economic and Strategic Rise of China and India: Asian Realignments after the 1997 Financial Crisis.

Review by Shalendra D. Sharma

Bruce J. Dickson, Wealth into Power: The Communist Party's Embrace of China's Private Sector.

David Shambaugh, China's Communist Party: Atrophy and Adaptation.

Review by David Bachman 
635 Bruce Gilley and Larry Diamond, eds. Political Change in China: Comparisons with Taiwan.

Alan M. Wachman, Why Taiwan? Geostrategic Rationales for China's Territorial Integrity. Review by Scott L. Kastner

637

638

640

640

642

643

\section{POLITICAL THEORY}

654 Michael Curtis, Orientalism and Islam: European Thinkers on Oriental Despotism in the Middle East and India. Review by Fred Dallmayr

Michael J. Green and Bates Gill, eds. Asia's New Multilateralism: Cooperation, Competition, and the Search for Community. Review by William W. Grimes

William W. Grimes, Currency and Contest in East Asia: The Great Power Politics of Financial Regionalism. Review by John Ravenhill

William Hurst, The Chinese Worker after Socialism. Review by Anita Chan

Hongyi Lai, Reform and the Non-State Economy in China: The Political Economy of Liberalization Strategies. Review by Andrew Wedeman

Huaiyin Li, Village China Under Socialism and Reform: A Micro-History, 1948-2008. Review by Mayling Birney

Tania Murray Li, The Will to Improve: Governmentality, Development, and the Practice of Politics.

Joseph Nevins and Nancy Lee Peluso, eds. Taking Southeast Asia to Market: Commodities, Nature and People in the Neoliberal Age. Review by Richard F. Doner

Andrew Mertha, China's Water Warriors: Citizen Action and Policy Change. Review by Victor Shih

Kevin J. O’Brien, ed. Popular Protest in China. Review by Andrew Mertha

Thomas B. Pepinsky, Economic Crisis and the Breakdown of Authoritarian Regimes: Indonesia and Malaysia in Comparative Perspective. Review by Edmund Malesky

Shalendra D. Sharma, China and India in the Age of Globalization. Review by David B.H. Denoon

Scott Snyder, China's Rise and the Two Koreas: Politics, Economics, Security. Review by David C. Kang

James W. Tong, Revenge of the Forbidden City: The Suppression of the Falungong in China, 1999-2005. Review by David Ownby

Alessandro Ferrara, The Force of the Example: Explorations in the Paradigm of Judgment. Review by Linda M. G. Zerilli

Raymond Geuss, Philosophy and Real Politics.

James Tully, Public Philosophy in a New Key. Vol. I: Democracy and Civic Freedom.

James Tully, Public Philosophy in a New Key. Vol. II: Imperialism and Civic Freedom. Review by Bonnie Honig

Dean Hammer, Roman Political Thought and the Modern Theoretical Imagination. Review by Benjamin Straumann

Ann Mongoven, Just Love: Transforming Civic Virtue. Review by Joan C. Tronto

Mark Olssen, Liberalism, Neoliberalism, Social Democracy: Thin Communitarian Perspectives on Political Philosophy and Education. Review by Sigal Ben-Porath

Davide Panagia, The Political Life of Sensation. Review by Robert E. Watkins

James H. Read, Majority Rule versus Consensus: The Political Thought of John C. Calhoun. Review by Thomas E. Schneider

Steven B. Smith, ed. The Cambridge Companion to Leo Strauss. Review by John R. Wallach

Stephen K. White, The Ethos of a Late-Modern Citizen. Review by Jason Frank

Alex Zakaras, Individuality and Mass Democracy: Mill, Emerson, and the Burdens of Citizenship. Review by Leonard Feldman

\section{AMERICAN POLITICS}

673 Jeremy D. Bailey, Thomas Jefferson and Executive Power.

Benjamin A. Kleinerman, The Discretionary President: The Promise and Peril of Executive Power. Review by Douglas A. Ollivant 
675 Karen L. Baird, with Dana-Ain Davis and Kimberly Christensen, Beyond Reproduction: Women's Health, Activism, and Public Policy.

Karen M. Kedrowski and Marilyn Stine Sarow, Cancer Activism: Gender, Media, and Public Policy. Review by Karen Beckwith

677 Jack M. Balkin and Reva B. Siegel, eds. The Constitution in 2020.

Sanford Levinson, Our Undemocratic Constitution: Where the Constitution Goes Wrong (And How We the People Can Correct It).

Cass Sunstein, A Constitution of Many Minds: Why the Founding Document Doesn't Mean What It Meant Before. Review by Mark A. Graber

679 Chris W. Bonneau and Melinda Gann Hall, In Defense of Judicial Elections.

James L. Gibson and Gregory A. Caldeira, Citizens, Courts, and Confirmations: Positivity Theory and the Judgments of the American People.

Review by Paul M. Collins, Jr.

681 Saul Brenner and Joseph W. Whitmeyer, Strategy on the United States Supreme Court.

H. Jefferson Powell, Constitutional Conscience: The Moral Dimensions of Judicial Decision.

Brian Z. Tamanaha, Beyond the Formalist-Realist Divide: The Role of Politics in Judging. Review by Eileen Braman

683 Jack Citrin and Isaac William Martin, eds. After the Tax Revolt: California's Proposition 13 Turns Thirty.

Isaac William Martin, The Permanent Tax Revolt: How the Property Tax Transformed American Politics. Review by Sheldon D. Pollack

Jocelyn Elise Crowley, Defiant Dads: Fathers' Rights Activists in America. Review by Mary Fainsod Katzenstein

Richard Gendron and G. William Domhoff, The Leftmost City: Power and Progressive Politics in Santa Cruz. Review by Matthew A. Crenson

Review by Anna-Maria Marshall

690 William G. Howell and Jon C. Pevehouse, While Dangers Gather: Congressional Checks on Presidential War Powers. Review by Ralph G. Carter

691 Karen M. Kaufmann, John R. Petrocik, and Daron R. Shaw, Unconventional Wisdom: Facts and Myths about American Voters.

Review by Michael S. Lewis-Beck

Jonathan Simon, Governing Through Crime: How the War on Crime Transformed American Democracy and Created a Culture of Fear.

Review by Jarret S. Lovell

Steven S. Smith and Melanie J. Springer, eds. Reforming the Presidential Nomination Process. Review by Martin Cohen

\section{COMPARATIVE POLITICS}

696 Vicki L. Birchfield, Income Inequality in Capitalist Democracies: The Interplay of Values and Institutions. Review by David R. Cameron

698 Rachel A. Cichowski, The European Court and Civil Society: Litigation, Mobilization and Governance. Review by Karen J. Alter

699 Chris Coulter, Bush Wives and Girl Soldiers: Women's Lives through War and Peace in Sierra Leone. Review by Dyan Mazurana

700 Zachary Elkins, Tom Ginsburg, and James Melton, The Endurance of National Constitutions. Review by Nathan J. Brown

702 Francisco E. González, Dual Transitions from Authoritarian Rule: Institutionalized Regimes in Chile and Mexico, $1970-2000$. Jon Shefner, The Illusion of Civil Society: Democratization and Community Mobilization in Low-Income Mexico.

Steven T. Wuhs, Savage Democracy: Institutional Change and Party Development in Mexico. Review by Eduardo Alemán

Mona Lena Krook, Quotas for Women in Politics: Gender and Candidate Selection Reform Worldwide. Review by Mark P. Jones

705 Timothy Longman, Christianity and Genocide in Rwanda. Review by Lee Ann Fujii

\section{INTERNATIONAL RELATIONS}

707 Giacomo Chiozza, Anti-Americanism and the American World Order. Review by Henry R. Nau

708 Ian Hurd, After Anarchy: Legitimacy and Power in the United Nations Security Council. Review by Mlada Bukovansky

710 Peter Katzenstein, ed. Civilizations in World Politics: Plural and Pluralist Perspectives. Review by Errol A. Henderson 
David A. Lake, Hierarchy in International Relations.

Review by Michael C. Williams

713 Richard Ned Lebow, A Cultural Theory of International Relations.

Review by lan Hurd

714 Steven E. Lobell, Norrin M. Ripsman, and Jeffrey W. Taliaferro, eds. Neoclassical Realism, the State, and Foreign Policy.

Review by Samuel Barkin

716

Walter Mattli and Ngaire Woods, eds. The Politics of Global Regulation.

Review by Mark R. Brawley

717 Manus I. Midlarsky, ed. Handbook of War Studies III: The Intrastate Dimension.

Review by David E. Cunningham

718

Helen V. Milner and Andrew Moravcsik, eds. Power, Interdependence, and Nonstate Actors in World Politics. Review by R. Harrison Wagner

Michael E. O’Hanlon, The Science of War: Defense Budgeting, Military Technology, Logistics, and Combat Outcomes. Review by Jonathan D. Caverley

721

William E. Scheuerman, Hans Morgenthau: Realism and Beyond. Review by Thomas C. Walker

722 Benjamin N. Schiff, Building the International Criminal Court.

Michael J. Struett, The Politics of Constructing the International Criminal Court: NGOs, Discourse, and Agency. Review by Steven C. Roach

724

Valerie Sperling, Altered States: The Globalization of Accountability. Review by Philip G. Cerny

David Sylvan and Stephen Majeski, U.S. Foreign Policy in Perspective: Clients, Enemies, and Empire. Review by Jason W. Davidson

727

Ray Taras, Europe Old and New: Transnationalism, Belonging and Xenophobia.

Review by Andrew Geddes

728 Wallace J. Thies, Why NATO Endures.

Review by John S. Duffield

731 Review Index 


\section{Philosophy for Perspectives on Politics}

Perspectives seeks to nurture a political science public sphere, publicizing important scholarly topics, ideas, and innovations, linking scholarly authors and readers, and promoting broad reflexive discussion among political scientists about the work that we do and why this work matters.

A full-length copy of the editorial philosophy appears in Perspectives on Politics 8(1): 7-10 and also on the web at http://www.apsanet.org/ content_44375.cfm.

\section{Submission and Review}

For submission guidelines, please see http://www.apsanet.org/ content_44360.cfm.

Our editorial team discusses all submissions. Those that seem promising are evaluated by several external reviewers - with full confidentiality on both sides - and then accepted, returned for further revisions, or declined with suggestions of more appropriate venues for publication.

\section{Perspectives on Politics}

\section{Editor}

Jeffrey C. Isaac, Indiana University, 2009-

Associate Editors

Edwina Barvosa, University of California, Santa Barbara

Richard Battistoni, Providence College

Daniel Drezner, Fletcher School, Tufts University

Page Fortna, Columbia University

Marc Morjé Howard, Georgetown University

Bryan Jones, University of Texas, Austin

Stathis Kalyvas, Yale University

Elizabeth S. Markovits, Mount Holyoke

Melissa Nobles, MIT

Timothy Kaufman-Osborn, Whitman College

Paul Pierson, University of California, Berkeley

James Scott, Yale University

Dara Strolovitch, University of Minnesota

Lisa Wedeen, University of Chicago

\section{Managing Editor}

\section{James Moskowitz}

Assistants to the Editor

Adrian Florea, Emily Hilty, Carolyn Holmes, Margot Morgan, Katie Scofield, Rebekah Tromble
Association Office Address and Membership Information: American Political Science Association individual membership dues are as follow: Regular members with income $\$ 100,000+, \$ 208 ; \$ 80,000-\$ 99,999, \$ 178 ; \$ 60,000-\$ 79,999$, $\$ 160 ; \$ 50,000-\$ 59,999, \$ 148 ; \$ 40,000-\$ 49,999$, \$126; less than $\$ 40,000, \$ 84$; Student members, $\$ 40$; Retired members with income $\$ 25,000+$, \$57: Retired members with income less than $\$ 25,000$, \$35; Life members: $\$ 3,000$; Unemployed members: \$40; Associate member with one journal selection, $\$ 52$. The amount of the dues allocated for a subscription is $\$ 6$ for an individual membership. Changes of address for members should be completed online or mailed to the APSA membership office at: APSA, 1527 New Hampshire Avenue, N.W. Washington, DC 20036

Subscription, Publishing, and Advertising Office Address: Cambridge University Press, 32 Avenue of the Americas, New York, NY 10013; and (for correspondents outside the United States, Canada, and Mexico) Cambridge University Press, The Edinburgh Building, Shaftesbury Road, Cambridge CB2 8RU, England.

Subscription Information: Perspectives on Politics (ISSN 1537 5927) is published quarterly, in March, June, September, and December, by Cambridge University Press for the American Political Science Association. Annual institutional electronic-only subscription rate (2010) is US\$740 in the United States, Canada, and Mexico; $£ 400$ elsewhere. Annual institutional print-andelectronic subscription rate (2010) is US\$816 in the United States, Canada, and Mexico; 4436 elsewhere. Perspectives on Politics is sold only as part of a joint subscription with the American Political Science Review and PS: Political Science \& Politics. Single part rate (2010) is US\$76 in the United States, Canada, and Mexico; £41 elsewhere. Periodicals postage rate paid at New York, NY, and additional mailing offices. Postmaster: Send address changes to Perspectives on Politics, Cambridge University Press, 100 Brook Hill Drive, West Nyack, NY 10994-2133, U.S.A.

(c) the American Political Science Association 2010

All rights reserved. No part of this publication may be reproduced, in any form or by any means, electronic, photocopying, or otherwise, without permission in writing from Cambridge University Press. Permission inquiries from the USA, Mexico, and Canada should be addressed to the New York office of Cambridge University Press http://www. cambridge.org/us/ information/rights/contacts/newyork.htm; permission inquiries from elsewhere should be addressed to the Cambridge office http:// www.cambridge.org/uk/information/rights/contacts/ cambridge.htm; permission inquiries from Australia and New Zealand should be addressed to the Melbourne office http:// uww.cambridge.org/aus/information/contacts_melbourne.htm.

Permission to copy (for users in the U.S.A) is available from the Copyright Clearance Center, http://www.copyright.com, email:info@copyright.com. Specific written permission must be obtained for republication; contact the nearest Cambridge University Press office.

Individual Copies: Single copies of Perspectives on Politics may be purchased for $\$ 25.00$

Microfilm Editions: Microfilm editions of Perspectives on Politics are available from ProQuest Information and Learning Ann Arbor, Ml 48106. (800) 521-0600.

Advertising: Perspectives on Politics has a circulation of 16,000 . For information on advertising rates and mechanical requirements, contact Advertising Coordinator, Cambridge University Press, 32 Avenue of the Americas, New York, NY 10013. (212) 337-5000.

Composition: Beljan, Ltd., Dexter, MI.

Printing and Distribution: The Sheridan Press, Hanover, PA

Reprint Permissions: Reprints of Perspectives articles for class use are available through the Academic Permissions Service of the Copyright Clearance Center, 222 Rosewood Drive, Danvers, MA 01923; phone: (978) 750-8400; fax: (978) 7504744; or online at www.copyright.com. 


\section{About APSA}

Founded in 1903, the American Political Science Association is the leading professional organization for the study of political science and serves more than 15,000 members in over 80 countries. With a range of programs and services for individuals, departments, and institutions, APSA brings together political scientists from all fields of inquiry, regions, and occupational endeavors within and outside academe in order to expand awareness and understanding of politics.

The direct advancement of knowledge is at the core of APSA activities. We promote scholarly communication in political science through a variety of initiatives including publishing three distinguished journals: American Political Science Review, Perspectives on Politics, and PS: Political Science and Politics.

\section{Officers}

\section{PRESIDENT}

Henry E. Brady

University of California, Berkeley

\section{PRESIDENT-ELECT}

Carole Pateman

University of California, Los Angeles

\section{VICE-PRESIDENTS}

Michael A. Jones-Correa

Cornell University

Jane Y. Junn

University of Southern California

Atul Kohli

Princeton University

\section{SECRETARY}

Roxanne L. Euben

Wellesley College

\section{TREASURER}

Arthur Lupia

University of Michigan

\section{PROGRAM CO-CHAIRS}

Andrea Campbell

Massachusetts Institute of Technology

Lisa L. Martin

University of Wisconsin, Madison

\section{EDITOR, APSR}

Ronald Rogowski

University of California, Los Angeles

\section{EDITOR, PERSPECTIVES}

Jeffrey Isaac

Indiana University

\section{EXECUTIVE DIRECTOR}

Michael Brintnall

American Political Science

Association

\section{Council}

\section{8-2010}

Jonathan Benjamin-Alvarado

University of Nebraska at Omaha

Jodi Dean

Hobart and William Smith Colleges

Kathleen Hall Jamieson

University of Pennsylvania

Rose McDermott

Brown University

Maria Victoria Murillo

Columbia University

Mark A. Peterson

University of California, Los Angeles

Sherri L. Wallace

University of Louisville

Franke Wilmer

Montana State University, Bozeman

2009-2011

Cristina Beltrán

Haverford College

Yun-han Chu

Academia Sinica/National Taiwan

University

Mark A. Graber

University of Maryland

Evelyne Huber

University of North Carolina,

Chapel Hill

Thomas E. Mann

Brookings Institution

Joseph P. McCormick II

Pennsylvania State University, York

Julie Novkov

State University of New York,

Albany

S. Laurel Weldon

Purdue University

\section{Former APSA Presidents}

Frank J. Goodnow

Albert Shaw

Frederick N. Judson James Bryce

A. Lawrence Lowell

Woodrow Wilson

Simeon E. Baldwin

Albert Bushnell Hart

W. W. Willoughby

John Bassett Moore

Ernst Freund

Jesse Macy

Munroe Smith

Henry Jones Ford

Paul S. Reinsch

Leo S. Rowe

William A. Dunning

Harry A. Garfield

James W. Garner

Charles E. Merriam

Charles A. Beard

William Bennett Munro

Jesse S. Reeves

John A. Fairlie

Benjamin F. Shambaugh

Edward S. Corwin

William F. Willoughby

Isidor Loeb

Walter Shepard

Francis W. Coker

Arthur N. Holcombe

Thomas Reed Powell

Clarence A. Dykstra

Charles Grove Haines

Robert C. Brooks

Frederic A. Ogg

William Anderson

Robert E. Cushman

Leonard D. White

John Gaus

Walter F. Dodd

Arthur W. MacMahon

Henry R. Spencer

Quincy Wright

James K. Pollock

Peter H. Odegard

Luther Gulick

Pendleton Herring

Ralph J. Bunche

Charles McKinley

Harold D. Lasswell

E. E. Schattschneider

V. O. Key Jr.
R. Taylor Cole

Carl B. Swisher

Emmette S. Redford

Charles S. Hyneman

Carl J. Friedrich

C. Herman Pritchett

David B. Truman

Gabriel A. Almond

Robert A. Dahl

Merle Fainsod

David Easton

Karl W. Deutsch

Robert E. Lane

Heinz Eulau

Robert E. Ward

Avery Leiserson

Austin Ranney

James MacGregor Burns

Samuel H. Beer

John C. Wahlke

Leon D. Epstein

Warren E. Miller

Charles E. Lindblom

Seymour Martin Lipset

William H. Riker

Philip E. Converse

Richard F. Fenno Jr.

Aaron B. Wildavsky

Samuel P. Huntington

Kenneth N. Waltz

Lucian W. Pye

Judith N. Shklar

Theodore J. Lowi

James Q. Wilson

Lucius J. Barker

Charles O. Jones

Sidney Verba

Arend Lijphart

Elinor Ostrom

M. Kent Jennings

Matthew Holden Jr.

Robert O. Keohane

Robert Jervis

Robert D. Putnam

Theda Skocpol

Susanne Hoeber Rudolph Margaret Levi

Ira Katznelson

Robert Axelrod

Dianne M. Pinderhughes

Peter Katzentstein 


\section{American Political Science Association}

\section{eJobs: Your Online Resource for Political Science Careers and Candidates}

APSA's eJobs is a year-round, online resource for political science employment opportunities and job candidates. It contains the most comprehensive online database of political science jobs, is updated daily with new job listings and candidate resumes, and is fully searchable by field of interest, name of employer/candidate, region, keyword, position, salary, type of institution, and most recent listings.

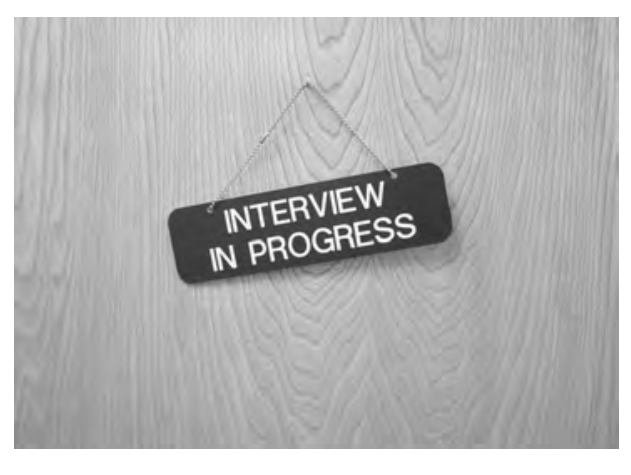

\section{How Does eJobs Work?}

\section{Job Candidates}

APSA members can access all open job listings and post their resume online to share with prospective employers by logging in to www.apsanet.org with your MyAPSA member login. The service is free to and offered exclusively to APSA members. Only APSA members can access the job listings or post their resumes to share with prospective employers. We encourage non-members who are interested in the service to join APSA now.

\section{Employers}

Employers who are APSA Departmental Services Program (DSP) members may post an unlimited number of job listings to share with prospective candidates and may search the all available resumes free of charge. Employers who are not DSP members may advertise positions for a fee. Non-member employers who have posted a job listing can also access the candidate resumes.

Member and non-member employers can access eJobs by logging in to www.apsanet.org with their DSP login. Non-member employers: for more information on the DSP, contact dsp@apsanet.org.

\section{Printed Job Listings in the PS: Political Science and Politics Supplement}

APSA prints eJobs job listings in a supplement to the APSA journal PS: Political Science \& Politics. The supplement accompanies PS each quarter (January, April, July and October) and includes job listings, upcoming conferences, tables of contents of forthcoming APSA journals, and other news in the profession. The print listing is free of charge to employers who post job listings on eJobs.

\section{www.apsanet.org/ejobs}

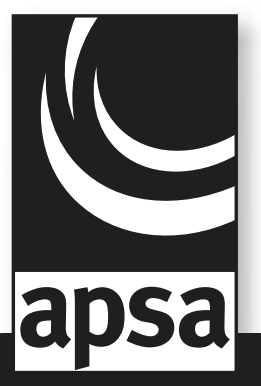

